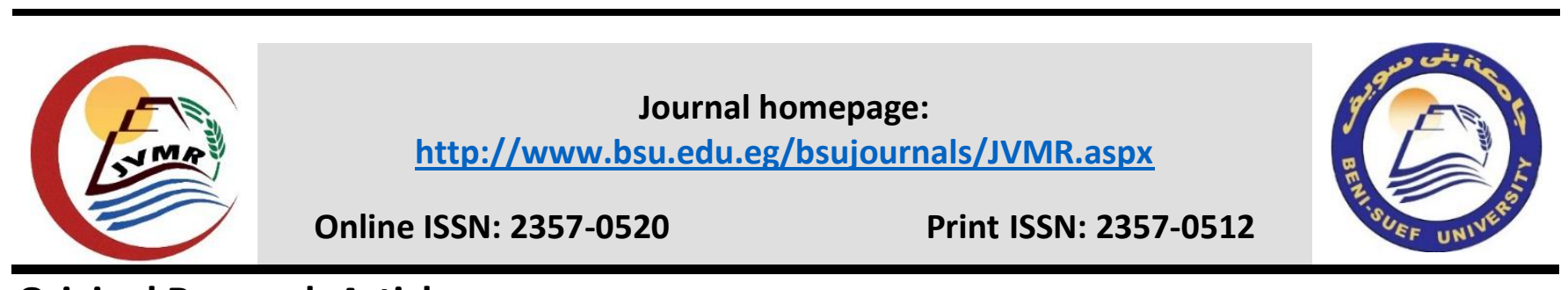

Original Research Article

\title{
A study on the effect of age, breed and season on sexual behaviour, testosterone concentrations and scrotal circumference in Egyptian rams
}

\author{
Ahmad S. Mostafa, Mostafa M. Farghal \\ Department of Animal Behaviour, Management and Development of Animal Wealth, Faulty of \\ Veterinary Medicine, Minia University.
}

\begin{abstract}
The objective of this study was to detect the influence of age, breed and season on sexual behaviour, testosterone concentrations and scrotal circumference in Egyptian rams. The study was carried out at agricultural research center belonging to Minia University, Shosha village, Samalut city, El-Minia. Ten crossbred and five adult Ossimi rams were used during this study. Every ram was allowed to breed two ewes to evaluate its sexual behaviour for a twenty minutes test. Blood samples were collected three times per season at two weeks interval from each ram during the period of experiment to measure testosterone concentrations. Also, scrotal circumference was measured at the same frequency and time interval as blood samples. Sexual behaviour was better in old rams than young ones $(p<0.01)$, but it was not affected by breed or season $(p>0.05)$. Serum testosterone level was higher at autumn $(7.13 \pm 02.9 \mathrm{ng} / \mathrm{ml})$ than at winter $(5.54 \pm 0.29 \mathrm{ng} / \mathrm{ml})$ in crossbred rams $(\mathrm{p}<0.01)$, while in Ossimi rams, higher level was obtained in spring $(8.24 \pm .39 \mathrm{ng} / \mathrm{ml})$ than in summer $(3.99 \pm 0.40$ $\mathrm{ng} / \mathrm{ml})$. Mean scrotal circumference was higher in older rams $(30.20 \pm 1.20$ $\mathrm{cm})$ than younger rams $(22.53 \pm 1.27 \mathrm{~cm})$. There was no significant difference for measures of scrotal circumference between crossbred rams $(30.86 \pm 1.09$ $\mathrm{cm})$ and Ossimi rams $(30.93 \pm 1.06 \mathrm{~cm})$. Season had no significant effect on scrotal circumference in crossbred rams, whereas in Ossimi rams the effect of season was significantly obvious with the highest and lowest values were recorded in spring $(31.0 \pm 1.05 \mathrm{~cm})$ and winter $(30.60 \pm 1.17 \mathrm{~cm})$ respectively. It could be concluded from this study that the age of rams had a great influence on their sexual behaviour and scrotal circumference, while the effect of breed and season on sexual behaviour and scrotal circumference was not clear.
\end{abstract}

*Corresponding author. Department of Animal Behaviour, Faculty of Veterinary Medicine, Beni-Suef University, Beni-Suef 62511, Egypt. 


\section{Introduction}

Sexual performance of rams is influenced by many factors including age, breed and season. Tests used for measuring the frequency and the duration of sexual behaviour elements like sniffing and nudging are beneficial in detecting differences in the sexual performance of different rams (Simitzis et al., 2006). These tests consist of exposing rams individually to a group of females in a small place for a certain period of time (Price, 1987). It is very important to minimize problems, which are associated with sexual behaviour (Simitzis et al., 2006). This study is concerned with elements of sexual behaviour which are indispensable for a successful mating.

Seasonal variation had a great effect on sexual behaviour, testosterone concentrations and scrotal circumference of rams (Casao et al., 2010).

Testosterone hormone has a fundamental role in the reproductive behaviour of rams and their secondary sexual characteristics (Hafez and Hafez, 2013). Serum testosterone levels can be influenced by some factors such as age of rams (Zamiri and Khodaei, 2005), breed (Hassanin et al., 2013) and season (Zamiri and Khodaei, 2005, Boland et al., 1985).

Furthermore, it was reported in earlier researches that scrotal circumference was significantly affected by age of the ram (Ribeiro et al., 2018), breed of the ram (Aller et al., 2012) and season (Hedia et al., 2019).

The aim of this study was to investigate the effect of age, breed and season on sexual behaviour, testosterone concentrations and scrotal circumference in Egyptian rams.

\section{Materials and Methods}

2.1 Animals:
Ten crossbred (Ossimi x Baladi) and five Ossimi rams were selected at agricultural research center belonging to Minia University, Shosha village, Samalut city, El-Minia and subjected to the study. According to age, crossbred rams were assigned to two groups; first group (3-4 years) and second group (9-12 months).

\subsection{Behavioural observation:}

Rams were allowed to mate with synchronized ewes with two doses of $1 \mathrm{ml}$ of prostaglandin F2 alpha (Ovuprost, Bayer Company, New Zealand) with interval of 11 days between the two doses for measuring of sexual behaviour. Every ram was allowed to breed two ewes for a twenty minutes test. This experiment was carried out at pen $(5 \times 8 \mathrm{~m})$ designed for this purpose:

Sexual behaviour characteristics were recorded by direct personal observation which includes sniffing (number/ test period), nudging (number/ test period), flehmen (number/ test period), frequency of vocalization (number/ test period), ejaculation duration (time in seconds), frequency of ejaculations (number/ test period), mounting duration (time in seconds), frequency of mountings (number/ test period) and duration between ejaculations (time in seconds).

\subsection{Blood sampling and analysis:}

Blood samples were collected from jugular vein at $(10.00$ a.m. $)$ three times for each season (autumn, winter, spring and summer) at two weeks interval from each ram during the period of experiment and centrifuged at $3000 \mathrm{rpm}$ for $15 \mathrm{~min}$. The obtained serum was stored until hormone analysis at $-20^{\circ} \mathrm{C}$. The concentration of testosterone in serum was measured in all samples by ELISA technique (Shrivastav et al., 2003). 


\subsection{Scrotal circumference:}

Scrotal circumference was measured 3 times for each season (autumn, winter, spring and summer) at 2 weeks interval for each ram during the period of experiment by grasping the neck of the scrotum with the hand using the fingers to push the testicles ventrally. The measuring tape was passed around the scrotum and tightened at the greatest width of the two testicles and measured in centimeters.

\subsection{Statistical analysis:}

Results were tabulated as mean \pm standard error (S.E). All data were analyzed by using nonparametric tests (Mann-Whitney Test, Friedman Test and Wilcoxon Signed Ranks Test) due to the non-normality of the data due to its low sample size. SPSS software (version 23, 2015) was used for the data analysis.

\section{Results}

Significant difference in elements of sexual behaviour was found between old and young crossbred rams except for sniffing (Table 1).

There was no difference in the frequency of sniffing between old and young rams ( $p>0.05)$. Old rams nudged ewes more than the young rams did $(\mathrm{p}<0.05)$. on the other hand, frequency of vocalization, frequency of mounting, mounting duration, ejaculation and duration between ejaculation differed significantly $(p<0.05)$ between old and young rams that failed to mount the ewes and ejaculate. Both old and young rams failed to show flehmen response during the period of experiment.

\section{Table (1): Effect of age on sexual behaviour characteristics of crossbred rams}

\begin{tabular}{llll}
\hline Characteristics & \multicolumn{2}{c}{ Rams } & p-value \\
\cline { 2 - 3 } & Old & Young & \\
\hline Sniffing & $1.20 \pm .58$ & $1.20 \pm .58$ & 1.00 \\
Nudging & $6.20 \pm 1.83^{\mathrm{a}}$ & $0.00^{\mathrm{b}}$ & .005 \\
Number of vocalization & $9.20 \pm 4.16^{\mathrm{a}}$ & $0.20 \pm .20^{\mathrm{b}}$ & .034 \\
Mounting frequency & $14.40 \pm 4.08^{\mathrm{a}}$ & $0.00^{\mathrm{b}}$ & .019 \\
Mounting duration & $9.20 \pm 5.49^{\mathrm{a}}$ & $0.00^{\mathrm{b}}$ & .019 \\
Frequency of ejaculation & $2.0 \pm .55^{\mathrm{a}}$ & $0.00^{\mathrm{b}}$ & .018 \\
Duration between ejaculations & $2.40 \pm .81^{\mathrm{a}}$ & $0.00^{\mathrm{b}}$ & .018 \\
\hline
\end{tabular}

Results are expressed as means \pm S.E,

Means within a row with different letters are significantly different at $\mathrm{P}<0.05$.

The results in Table (2) showed that breed difference has no effect on components of sexual behaviour except for flehmen response and mounting duration. Ossimi sheep showed flehmen response $(\mathrm{p}<0.05)$ during courtship but this was not observed in crossbred rams.
Mounting duration was significantly shorter in Ossimi rams than crossbred ones. Other elements of sexual behaviour did not differ significantly between Ossimi and crossbred rams ( $p>0.05)$. 
Table (2): Effect of breed of ossimi and crossbred rams on their sexual behaviour characteristics.

\begin{tabular}{llll}
\hline \multirow{2}{*}{ Characteristics } & \multicolumn{2}{c}{ Rams } & p-value \\
\cline { 2 - 3 } & Ossimi & crossbred & \\
\hline Flehmen & $2.80 \pm 3.7^{\mathrm{a}}$ & $0.00^{\mathrm{b}}$ & $<.05$ \\
Sniffing & $3.0 \pm .70$ & $2.2 \pm .58$ & $>.05$ \\
Nudging & $8.8 \pm 1.16$ & $6.8 \pm 1.49$ & $>.05$ \\
Number of vocalization & $11.6 \pm 1.94$ & $8.6 \pm 3.14$ & $>.05$ \\
Mounting frequency & $17.6 \pm 1.20$ & $13.6 \pm 3.94$ & $>.05$ \\
Mounting duration & $2.2 \pm .37$ & $7.4 \pm 4.04$ & $>.05$ \\
Frequency of ejaculation & $2.6 \pm 2.4$ & $2.0 \pm .55$ & $>.05$ \\
Duration between ejaculations & $3.2 \pm .58$ & $2.6 \pm .87$ & $>.05$ \\
\hline Results are expressed as means & & &
\end{tabular}

Results are expressed as means \pm S.E,

Means within a row with different letters are significantly different at $\mathrm{P}<0.05$.

The effect of season on characteristics of sexual behaviour of old crossbred rams was illustrated in Table (3). It was declared from the obtained results that there was no significant $(p>0.05)$ effect for season on characteristics of sexual behaviour of crossbred rams.

Table (3): Effect of season on characteristics of sexual behaviour of old crossbred rams.

\begin{tabular}{llll}
\hline Characteristics & \multicolumn{2}{c}{ Old crossbred rams } & p-value \\
\cline { 2 - 3 } & Autumn & Winter & \\
\hline Sniffing & $1.20 \pm .58$ & $2.2 \pm .58$ & $>.05$ \\
Nudging & $6.20 \pm 1.83$ & $6.8 \pm 1.49$ & $>.05$ \\
Number of vocalization & $9.20 \pm 4.16$ & $8.6 \pm 3.14$ & $>.05$ \\
Mounting frequency & $14.40 \pm 4.08$ & $13.6 \pm 3.94$ & $>.05$ \\
Mounting duration & $9.20 \pm 5.49$ & $7.4 \pm 4.04$ & $>.05$ \\
Frequency of ejaculation & $2.0 \pm .55$ & $2.0 \pm .55$ & $>.05$ \\
Duration between ejaculations & $2.40 \pm .81$ & $2.6 \pm .87$ & $>.05$ \\
\hline
\end{tabular}

Results are expressed as means \pm S.E,

Means within a row with different letters are significantly different at $\mathrm{P}<0.05$.

The results obtained from Table (4) showed that there was a highly significant $(\mathrm{p}<0.01)$ difference in serum testosterone level between autumn and winter seasons in crossbred rams. Serum testosterone level was higher at autumn $(7.13 \pm 02.9 \mathrm{ng} / \mathrm{ml})$ than at winter season $(5.54 \pm 0.29 \mathrm{ng} / \mathrm{ml})$. Moreover, there was a significant $(\mathrm{p}<0.01)$ great variation in testosterone level between different seasons as measured in Ossimi rams. The highest value of testosterone was recorded in spring (8.24 4.39 $\mathrm{ng} / \mathrm{ml}$ ) and the lowest value was recorded in summer $(3.99 \pm 0.40 \mathrm{ng} / \mathrm{ml})$. 
Table (4): Effect of season on serum testosterone levels of crossbred and Ossimi rams

\begin{tabular}{|c|c|c|c|c|}
\hline \multirow{4}{*}{ Crossbred rams } & \multicolumn{3}{|c|}{ Serum testosterone level (ng/ml) } & \multirow[t]{2}{*}{ p-value } \\
\hline & Autumn & & Winter & \\
\hline & $7.13 \pm 02.9^{\mathrm{a}}$ & & $5.54 \pm 0.29^{b}$ & 0.00 \\
\hline & Winter & Spring & Summer & \\
\hline Ossimi rams & $4.86 \pm 0.50^{\mathrm{a}}$ & $8.24 \pm .39^{b}$ & $3.99 \pm 0.40^{\mathrm{c}}$ & 0.001 \\
\hline
\end{tabular}

Results are expressed as means \pm S.E,

Means within a row with different letters are significantly different at $\mathrm{P}<0.05$.

Regarding scrotal circumference, it was clear that there was a highly significant $(\mathrm{p}<0.01)$ difference between old $(30.20 \pm 1.20 \mathrm{~cm})$ and young $(22.53 \pm 1.27 \mathrm{~cm})$ crossbred rams (Table $5)$. Concerning the effect of breed on scrotal circumference, it was obvious that there was no significant $(\mathrm{p}>0.05)$ difference between Ossimi $(30.86 \pm 1.09 \mathrm{~cm})$ and crossbred rams $(30.93 \pm 1.06 \mathrm{~cm})$.

\section{Table (5): Effect of age and breed on scrotal circumference of crossbred rams and Ossimi rams}

\begin{tabular}{llll}
\hline \multirow{2}{*}{ Age } & \multicolumn{2}{c}{ Scrotal circumference $(\mathbf{c m})$} & p-value \\
\cline { 2 - 3 } Breed & Old rams & Young rams & \\
\cline { 2 - 3 } & $30.20 \pm 1.20^{\mathrm{a}}$ & $22.53 \pm 1.27^{\mathrm{b}}$ & \\
& Old rams & Ossimi rams & 0.91 \\
\hline
\end{tabular}

Results are expressed as means \pm S.E,

Means within a row with different letters are significantly different at $\mathrm{P}<0.05$.

From Table (6), it could be concluded that scrotal circumference of old crossbred rams was higher in autumn season than in winter season although this difference was not significant ( $>0.05)$. Additionally, the effect of season on scrotal circumference was significant $(\mathrm{p}<0.05)$ in Ossimi rams, where the highest value was recorded in spring and the lowest value was recorded in winter.

\section{Table (6): Effect of season on scrotal circumference of crossbred and Ossimi rams}

\begin{tabular}{|c|c|c|c|c|}
\hline & \multicolumn{2}{|c|}{ Scrotal circumference $(\mathrm{cm})$} & & \multirow[t]{2}{*}{ p-value } \\
\hline & Autumn & Winter & & \\
\hline Crossbred rams & $30.40 \pm 1.40^{\mathrm{a}}$ & $29.8 \pm .97^{\mathrm{a}}$ & & $>0.05$ \\
\hline & Winter & Spring & Summer & \\
\hline Ossimi rams & $30.60 \pm 1.17^{\mathrm{a}}$ & $31.0 \pm 1.05^{\mathrm{b}}$ & $32.0 \pm 1.05^{\mathrm{c}}$ & $<0.05$ \\
\hline
\end{tabular}

Results are expressed as means \pm S.E,

Means within a row with different letters are significantly different at $\mathrm{P}<0.05$. 


\section{Discussion}

a. Effect of age on sexual behaviour characteristics of crossbred rams

All the behavioural components were significantly increased in case of old rams than young rams except for sniffing (Table 1). Neither old nor young rams showed flehmen response during the period of experiment. As it was illustrated from the fore mentioned results, old rams exhibited higher rates of sexual interest in comparison to young ones. Young rams failed to show components of sexual behaviour except for sniffing and vocalization. So, we can ascribe the variation in characteristics of sexual behaviour to the age difference of rams in the same breed. It was found that the age of rams had a significant effect on its sexual behaviour (Simitzis et al., 2006). Higher sexual interest of old rams may be due to its previous sexual experience, while young rams without any previous experience failed even to identify estrous ewes, which may be due to its failure to identify the pheromones of ewes. Moreover, low testosterone hormone may be a contributing factor. In contrast, old rams have faster ewe pheromone perception and higher concentrations of testosterone hormone. Concentrations of testosterone hormone was found to be lower in sexually inactive than sexually active rams when exposed to estrus ewes (Perkins et al., 1992, Alexander et al., 1999, Stellflug et al., 2004). Also, the libido in young rams is lower when exposed to ewes for the first time than during subsequent exposures (Price et al., 1991). Sexual behaviour was better in adult Ossimi rams (2-2.5years) than the young (1-1.5 years) rams of the same breed (Mahmoud, 2013). This result was similar to that obtained in previous studies (Perkins et al.,
1992, Alexander et al., 1999, Stellflug et al., 2004).

b. Effect of breed of rams on sexual behaviour characteristics

Elements of sexual behaviour were not significantly affected by breed except for flehmen response and mounting duration (Table 2). Frequency of flehmen response was higher in Ossimi than crossbred rams $(\mathrm{p}<0.05)$, but other components of sexual behaviour did not differ significantly between breeds ( $p>0.05$ ).

Breed effect on components of sexual behaviour was little especially when the other housing conditions, climate and nutritional level are the same. Sexual performance of rams was not only affected by breed but also there are many other factors that may affect it including genetics, season of year, hormonal influence, management and nutrition (Mickelsen et al., 1981).

The current results agree with that reported by Aller et al. (2012) who found that there was no difference between Corriedale and Pampinta rams in sexual behaviour, as well as Bozkurt (2012) who reported that sexual performance did not differ between kivircik and White karaman rams. On the contrary,it was found that Saint Croix rams had better sexual performance than Suffolk rams (Clemente et al., 2013). Furthermore, sexual performance was higher in Awassi than the Charollais-Awassi and Romanov-Awassi rams (Rams, 2006).

c. Effect of season on characteristics of sexual behaviour of old crossbred rams

Table (3) illustrated that seasonal variation did not significantly affect sexual behaviour of crossbred rams $(p>0.05)$. This result is parallel 
to prior researches by Taha et al. (2000) who clarified that sexual behaviour of Barki and Awassi rams was not affected by seasonal variation and Kafi et al. (2004) who demostrated that there was no effect for season on sexual performance of Persian Karakul rams. The effect of season was not clear in the obtained results due to other contributing factors which may influence sexual behaviour of rams kept under the conditions of the experiment such as management and nutrition.

In contrast, Hakeam et al. (1978) found that sexual performance of Ossimi rams was greater in spring than in winter season. Moreover, Aller et al. (2012) reported that Corriedale and Pampinta rams had better sexual performance in winter and autumn $(\mathrm{p}<0.05)$ than other seasons of the year.

\section{d. Effect of season on serum testosterone levels of crossbred and Ossimi rams}

There was a significant $(\mathrm{p}<0.01)$ high level of testosterone in crossbred rams at autumn than at winter season (Table 4). There is a great variation in the level of testosterone among different seasons in Ossimi rams. It was higher in spring than winter and summer. So, seasonal variation has a great effect on level of testosterone hormone which is consistent with previous studies (Dufour et al., 1984, Sanford et al., 2000, Fernandez et al., 2004). Furthermore, testosterone concentrations were higher in autumn $(17.81 \pm 0.7 \mathrm{ng} / \mathrm{ml})$ than in winter $(2.31 \pm 0.14 \mathrm{ng} / \mathrm{ml})$ in Racka rams (Sarlós et al., 2013). Some researchers reported that testosterone concentrations were higher in autumn than other seasons of the year in Moghani rams (Zamiri et al., 2010), while ElDarawany. (1999) declared that the lowest level of testosterone was measured during summer in Ossimi rams because long daylight inhibits their secretion while short daylight stimulates their secretion.

Contrarily, Taha et al. (2000) clarified that the highest level of testosterone was recorded in summer season in Barki and Awassi rams as well as Aller et al. (2012) who found the same results in Pampinta and Corriedale rams, while Marai et al. (1992) reported that testosterone concentrations were insignificantly influenced by season in Ossimi x Suffolk rams.

e. Effect of age and breed on scrotal circumference of crossbred and Ossimi rams

The age has a great effect on scrotal circumference of rams as it was illustrated in Table (5). It was higher in old than young crossbred rams. This is probably due to the higher body weight of old rams $(58.60 \pm 4.75 \mathrm{~kg})$ compared to young rams $(40.50 \pm 2.64 \mathrm{~kg})$. It was reported that there was a significant correlation between body weight and scrotal circumference of rams (Fourie et al., 2002, Duguma et al., 2002, Rams, 2006). This result is in line with Ribeiro et al. (2018) who demonstreted that adult Santa Ines rams (12 to 26 months) had higher scrotal circumference than young Santa Ines rams (6 to 12 months) as well as Elmaz et al. (2007) who declared that young Kivircik rams had lower scrotal circumference than adult Kivircik rams.

From the results obtained in Table (5), it was clear that breed had no influence on scrotal circumference in Ossimi and crossbred rams ( $>>0.05)$. Mean scrotal circumference was $(30.86 \pm 1.09 \mathrm{~cm})$ and $(30.93 \pm 1.06 \mathrm{~cm})$ in both crossbred and Ossimi rams respectively which may be related primarily to the similarity in body weight between crossbred $(58.60 \pm 4.75 \mathrm{~kg})$ and Ossimi $(65 \pm 2.7 \mathrm{~kg}) \mathrm{rams}$; and secondarily due to the similarity in age, as the rams of the two groups had the same age (3-4 years). The 
obtained results disagree with Aller et al. (2012) who mentioned that Pampinta rams (34.4 \pm 0.4 $\mathrm{cm}$ ) had higher scrotal circumference than Corriedale rams $(32.8 \pm 0.3 \mathrm{~cm})$.

\section{f. Effect of season on scrotal circumference of crossbred and Ossimi rams}

The results in Table (6) illustrated that scrotal circumference of old crossbred rams was higher during autumn season $(30.40 \pm 1.40 \mathrm{~cm})$ than during winter season $(29.8 \pm .97 \mathrm{~cm})$ although the difference was not significant $(\mathrm{p}>0.05)$. Scrotal circumference of Ossimi rams was higher during summer, than during winter and spring. So, the season has a significant effect $(\mathrm{p}<0.05)$ on scrotal circumference of Ossimi rams. This is probably due to the relationship between testosterone hormone and scrotal circumference (Dufour et al., 1984, Kilgour et al., 1984, Matos and Thomas, 1992). Scrotal circumference was higher in the same periods in which testosterone concentration was higher and vice versa. This result agree with Hedia et al. (2019) who found that there was a significant effect for season on scrotal circumference in the studied five adult fat-tailed rams $(\mathrm{p}<0.01)$ with the maximum value in November and the lowest value in June as well as Milczewski et al. (2015) who reported that scrotal circumference of Suffolk rams was influenced by different seasons with the maximum value in summer and the minimum value in autumn and winter.

\section{Conclusion}

Sexual behaviour and consequently sexual performance of crossbred and Ossimi rams may be influenced by some factors such as age, breed difference and season. Old rams had better sexual performance than young ones. Some variations in sexual behaviour patterns and sexual performance may occur due to breed difference. Seasonal variation had no significant effect on sexual behaviour. A great variation in testosterone level could occur in different breeds of rams in relation to seasonal variations. Scrotal circumference was significantly influenced by age of the rams but there was no clear effect of breed and season in this respect.

\section{References}

ALEXANDER, B., STELLFLUG, J., ROSE, J., FITZGERALD, J. \& MOSS, G. 1999. Behavior and endocrine changes in highperforming, low-performing, and maleoriented domestic rams following exposure to rams and ewes in estrus when copulation is precluded. Journal of animal science, 77, 1869-1874.

ALlER, J. F., AGUILAR, D., VERA, T., ALMEIDA, G. P. \& ALBERIO, R. H. 2012. Seasonal variation in sexual behavior, plasma testosterone and semen characteristics of Argentine Pampinta and Corriedale rams. Spanish Journal of Agricultural Research, 10, 345.

BOLAND, M., AL-KAMALI, A., CROSBY, T., HAYNES, N., HOWLES, C., KELLEHER, D. \& GORDON, I. 1985. The influence of breed, season and photoperiod on semen characteristics, testicular size, libido and plasma hormone concentrations in rams. Animal Reproduction Science, 9, 241-252.

CASAO, A., MENDOZA, N., PEREZ-PE, R., GRASA, P., ABECIA, J. A., FORCADA, F., CEBRIáN-PEREZ, J. A. \& MUINO-BLANCO, T. 2010. Melatonin prevents capacitation and apoptotic-like changes of ram spermatozoa and increases fertility rate. Journal of pineal research, 48, 39-46.

CLEMENTE, N., ORIHUELA, A., FLORESPEREZ, I., AGUIRRE, V. \& VALENCIA, J. 2013. Reproductive behaviour of Saint Croix and Suffolk 
rams at medium latitudes $\left(19^{\circ} \mathrm{N}\right)$ during long days while being exposed to Suffolk ewes in seasonal anestrus. Archivos de Medicina Veterinaria, 45.

DUFOUR, J., FAHMY, M. \& MINVIELLE, F. 1984. Seasonal Changes in Breeding Activity, Testicular Size, Testosterone Concentration and Seminal Characteristics in Rams with Long or Short Breeding Season1. Journal of animal science, 58, 416-422.

DUGUMA, G., CLOETE, S., SCHOEMAN, S. \& JORDAAN, G. 2002. Genetic parameters of testicular measurements in Merino rams and the influence of scrotal circumference on total flock fertility. South African journal of animal science, 32, 76-82.

FERNANDEZ, M., GIRALDEZ, F., FRUTOS, P., LAViN, P. \& MANTECON, A. 2004. Effect of undegradable protein supply on testicular size, spermiogram parameters and sexual behavior of mature Assaf rams. Theriogenology, 62, 299-310.

FOURIE, P., NESER, F., OLIVIER, J. \& VAN DER WESTHUIZEN, C. 2002. Relationship between production performance, visual appraisal and body measurements of young Dorper rams. South African Journal of Animal Science, 32, 256-262.

HAFEZ, E. S. E. \& HAFEZ, B. 2013. Reproduction in farm animals, John Wiley \& Sons.

HASSANIN, S., HUSSEIN, A., KHATTAB, Y. \& ABDALLA, M. 2013. Reproductive performance of rams under arid conditions. Life Sci. J, 10, 2596-2506.

HEDIA, M. G., EL-BELELY, M. S., ISMAIL, S. T. \& ABO EL-MAATY, A. M. 2019. Monthly changes in testicular blood flow dynamics and their association with testicular volume, plasma steroid hormones profile and semen characteristics in rams. Theriogenology, 123, 68-73.

KILGOUR, R., PURVIS, I., PIPER, L. \& ATKINS, K. 1984. Heritabilities of testis size and sexual behaviour in males and their genetic correlations with measures of female reproduction. Genetics of reproduction in sheep/edited by $R B$ Land, DW Robinson.

MAHMOUD, G. 2013. Sexual behaviour, testosterone concentration, semen characteristics and testes size of Ossimi rams as affected by age and scrotal circumference. Egyptian Journal of Animal Production, 50, 53-58.

MATOS, C. \& THOMAS, D. 1992. Physiology and genetics of testicular size in sheep: a review. Livestock Production Science, 32, 1-30.

MICKELSEN, W. D., PAISLEY, L. G. \& DAHMEN, J. J. 1981. The effect of season on the scrotal circumference and sperm motility and morphology in rams. Theriogenology, 16, 45-51.

PERKINS, A., FITZGERALD, J. \& PRICE, E. 1992. Sexual performance of rams in serving capacity tests predicts success in pen breeding. Journal of animal science, 70, 2722-2725.

PRICE, E., ESTEP, D., WALLACH, S. \& DALLY, M. 1991. Sexual performance of rams as determined by maturation and sexual experience. Journal of animal science, 69, 1047-1052.

PRICE, E. O. 1987. Male sexual behavior. Veterinary Clinics of North America: Food Animal Practice, 3, 405-422.

RAMS, R.-A. 2006. Reproduction of Awassi and Crossbred Rams.

RIBEIRO, M., QUIRINO, C., BARTHOLAZZI JUNIOR, A., PACHECO, A., VEGA, W. \& RUA, M. 2018. Repeatability and effect of age on reproductive characteristics in Santa Ines rams. Archivos de zootecnia, 67. 
SANFORD, L., MOORE, C., VOGLMAYR, J. \& FAHMY, M. 2000. Sexual maturational changes in circulatory inhibin concentration in relation to $\mathrm{FSH}$ concentration and testicular size in Suffolk and DLS rams. Theriogenology, 54, 719-730.

SARLóS, P., EGERSZEGI, I., BALOGH, O., MOLNáR, A., CSEH, S. \& RáTKY, J. 2013. Seasonal changes of scrotal circumference, blood plasma testosterone concentration and semen characteristics in Racka rams. Small Ruminant Research, 111, 90-95.

SHRIVASTAV, T. G., BASU, A. \& KARIYA, K. P. 2003. One step enzyme linked immunosorbent assay for direct estimation of serum testosterone. Journal of Immunoassay and Immunochemistry, 24, 205-217. 